\title{
PERBEDAAN PERILAKU ANDROGINI DITINJAU DARI TEMPAT KERJA
}

\author{
Drs. Mulia Siregar, M.Psi \\ Fakultas Psikologi Universitas Medan Area
}

\begin{abstract}
Abstrak
Penelitian ini bertujuan untuk mengetahui perbedaan perilaku androgini ditinjau dari tempat kerja. Hipotesis dalam penelitian ini adalah ada perbedaan perilaku androgini ditinjau dari tempat kerja dimana penelitian ini dilakukan di Anonimo Coffee dan Cafe Rumah Pohon dengan total 39 karyawan. Metode yang digunakan dalam penelitian ini adalah metode kuantitatif dengan teknik pengambilan sampel adalah nonprobability sampling. Alat ukur yang digunakan adalah skala Guttman dengan satu skala yakni skala perilaku androgini. Analisis data yang digunakan adalah teknik analisis varians satu jalur. Adapun hasil perhitungan mean hipotetik, mean empirik, serta standar deviasinya diketahui bahwa perilaku adrogini yang bekerja di Cafe Rumah Pohon berada pada kategori tinggi, dengan skor mean hipotetik sebesar 63 dan skor mean empirik sebesar 37.14, serta standar deviasinya 3.399. Sedangkan perilaku androgini yang bekerja di Anonimo Coffee berada pada kategori cukup dengan skor mean hipotetik 63 dan mean empirik 31.71, serta standar deviasinya 4.858. Hasil penelitian menunjukkan bahwa ada perbedaan perilaku androgini ditinjau dari tempat kerja yakni pada Anonimo Coffee dan Cafe Rumah Pohon dengan melihat nilai atau koefisien perbedaan Anava dimana, $\mathrm{F}=16.874$ dengan $\mathrm{p}=0.000,<0,010$.
\end{abstract}

Kata kunci : Perilaku Androgini

\section{PENDAHULUAN}

Kategorisasi untuk identitas gender mencakup dua hal dalam pandangan tradisional (Scanzoni, 1981, dalam Sears, dkk., 1985), yakni maskulin dan feminin, yang tidak hanya terbatas pada persepsi terhadap manusia; berbagai objek dan kegiatan biasanya juga didefinisikan berdasarkan sifat maskulin dan feminin.

Berdasarkan pendapat tradisional menyatakan bahwa orang yang sehat itu adalah orang yang memiliki peran jenis sesuai dengan jenis kelaminnya namun pendapat seperti itu saat ini haruslah dikoreksi. Saat ini orang mulai berpendapat bahwa orang yang sehat adalah orang yang mempunyai sifat androgini (dalam Supriyanto, 2005).
Pada tahun 1977 Sandra L. Bem mengeluarkan sebuah inventory pengukuran gender yang diberi nama The Bem Sex-Role Inventory. Berdasarkan respon dari item-item pada inventory ini, individu diklasifikasikan memiliki salah satu dari orientasi peran gender yakni maskulin, feminin, androgini, dan tidak terdiferensiasi (undifferentiated) (dalam Santrock, 2007).

Menurut Bem, individu yang feminin adalah seseorang memiliki angka yang tinggi pada sifat feminin dan memiliki angka rendah dari sifat maskulin, individu yang maskulin adalah seseorang yang memiliki angka yang tinggi pada sifat maskulin dan memiliki angka yang rendah pada sifat feminin. Individu androgini adalah laki-laki atau 
perempuan yang memiliki angka tinggi pada sifat maskulin dan feminin. Individu undifferentiated memiliki angka yang rendah pada sifat maskulin dan femininnya.

Androgini berasal dari bahasa Yunani, secara harfiah andro ialah pria dan gyne ialah wanita. Bem menekankan bahwa seorang androginus bukanlah orang moderat, yang berada di tengah-tangah antara maskulin dan femininitas yang ekstrem. Tetapi seorang androginus memandang bahwa dirinya mampu mengombinasikan ciri-ciri maskulin dan feminin yang kuat (dalam Sears, dkk., 1985).

Berbeda halnya dengan Spence dan Helmreich (1978), seorang androgini memiliki harga diri tinggi, pandai bergaul, dan orientasi pada hasil tinggi. Heilbrun menyatakan androgini merupakan peran jenis yang memiliki skor yang tinggi baik sifat feminin maupun maskulin dan peran jenis androgini ini terdapat pada kedua jenis kelamin yaitu perempuan dan lakilaki.

Pada era globalisasi ini, semua hal dapat dilakukan baik oleh pria maupun wanita untuk memenuhi semua kebutuhan hidupnya. Baik pria maupun wanita dapat melakukan dua pekerjaan sekaligus, yang mana pekerjaan tersebut bersifat maskulin ataupun feminin, ini berbanding terbalik dengan peran gender tradisonal yang seharusnya. Sebagai contoh seorang pria dapat ahli dalam hal masak-memasak (feminin) namun ia mungkin juga menyukai hal-hal yang ekstrim seperti motor cross atau panjat tebing. Hal ini dapat dilihat pada salah satu aktor seperti Ceff Nurman dan Ceff Juna yang memiliki profesi sebagai seorang koki. Contoh lain dapat ditemukan pada seorang Menteri Indonesia yakni Ibu Susi sebagai Menteri perlautan dan Ibu Rahmi sebagai Gubernur Surabaya. Karakteristik androgini dapat ditemukan pada mereka sebagai contoh sosok androgini.

Karakteristik androgini merupakan perpaduan dari karakteristik maskulin dan feminin. Individu ini dapat menggabungkan peran jenis feminin dengan karakteristik dapat melakukan hubungan sosial yang baik, ramah terhadap orang lain dan peran jenis maskulin dengan karakteristik berdikari, memiliki kemampuan diri yang baik secara seimbang (Bem, dalam Imelda, 1993). Laki-laki digambarkan sebagai individu yang rasional dan memiliki kemampuan memimpin (Sahrah, 1996). Kemudian Raven dan Rubin (1983) menambahkan tentang sifat agresif, bebas, dominant, objektif, tidak emosional dan memiliki rasa ingin tahu yang tinggi merupakan ciri-ciri sifat yang dimiliki 
oleh laki-laki. Menurut Sahrah (1996) menggambarkan perempuan sebagai individu yang sensitif, berhati-hati dan suka menyenangkan orang lain. Feldman (1990) mengemukakan beberapa karakteristik feminin yaitu emosional, subjektif, tidak logis, suka mengeluh dan merajuk, lemah, putus asa, mudah tersinggung, tergantung pada orang lain. Sedangkan maskulin digambarkan memiliki karakteristik agresif, mandiri, tidak emosional, objektif, tidak mudah dipengaruhi orang lain, dapat mengambil keputusan, percaya diri, logis, kompetitif dan ambisius (Broveman, 2003).

Menurut Bem (1981), secara teoritis orang yang memiliki karakteristik androgini dapat mengadaptasi perilakuperilaku maskulin dan dapat memecahkan masalah dan mengadaptasi perilaku feminin. Wrightsman dan Deaux (dalam Nauly, 2003) menyebutkan bahwa seseorang yang androgini cenderung lebih kompeten, yakin pada diri sendiri dan memiliki harga diri yang tinggi. Selain itu dalam beberapa situasi cenderung fleksibel dan efektif dalam hubungan interpersonalnya (dalam Kisworo, R. D, 2008).

Bem juga berpendapat bahwa individu androgini memiliki sifat yang lebih fleksibel, kompeten, dan sehat mental dibandingkan dengan individu yang hanya memiliki sifat maskulin atau feminin (dalam Santrock, 2012). Menurut Bem sifat orang androgini mencakup lebih bebas, mengenali dirinya, dan suka membantu (dalam Elqorni, A. K, 2014).

Berbeda halnya dengan Spence dan Helmreich (1978), seorang androgini memiliki harga diri tinggi, pandai bergaul, dan orientasi pada hasil tinggi. Heilbrun menyatakan androgini merupakan peran jenis yang memiliki skor yang tinggi baik sifat feminin maupun maskulin dan peran jenis androgini ini terdapat pada kedua jenis kelamin yaitu, perempuan dan lakilaki.

Helmreich (1979) dalam hasil penelitiannya mengemukakan bahwa peran jenis androgini untuk kedua jenis kelamin (laki-laki dan perempuan) memiliki perilaku yang menyenangkan dan fleksibel dibandingkan ketiga peran jenis lainnya.

Selanjutnya, individu yang memiliki dimensi maskulin menekankan nilai asertivitas, prestasi, dan performansi. Sementara pada individu feminin lebih mengutamakan hubungan interpersonal, keharmonisan, dan kinerja kelompok.

Kaplan dan Sedney menyatakan ada beberapa faktor yang harus ada pada sifat androgini, yaitu: 
1. Mempunyai wawasan pandangan yang luas sehingga mampu bereaksi secara tepat dalam situasi apapun.

2. Mampu bersikap fleksibel seperti apa yang diharapkan oleh masyarakat (mampu membedakan kapan harus bersikap maskulin dan kapan harus bersikap feminin).

3. Mampu bersikap hangat dan diterima baik oleh orang lain (dalam Supriyanto, 2005).

Tipe androgini adalah tipe pria dan wanita yang mampu menggabungkan sifat maskulin dan feminin dalam kepribadian dan dimanifestasikan dalam perilaku sehar-hari dalam kondisi dan situasi yang tepat. Individu yang memiliki peran jenis androgini pada umumnya memiliki ketegasan diri, memiliki kemampuan diri yang baik serta dapat melakukan hubungan sosial dengan baik (Bem, dalam Betz \& Fitzgerald, 1987). Selain itu menurut Bakan 1987, ciri-ciri individu androgini yaitu adanya motivasi untuk maju atau memimpin (dalam Imelda \& Saifuddin, 1993).

Dunia kerja atau tempat kerja merupakan hal yang paling berkompeten dalam merealisasikan atau mempraktekkan karakter-karakter androgini. Pada dunia kerja, tidak hanya laki-laki atau pria saja mempuni dalam menjadi ketua atau atasan melainkan seorang wanita juga mempuni dalam jabatan tersebut. Contoh dunia kerja tau tempat kerja yang paling banyak di lingkungan makanan cepat saji dimana tempat tersebut paling cepat ditemukan. Restoran atau cafe merupakan tempat kerja yang paling mudah ditemukan. Tempat kerja tersebut memiliki anggota karyawan yang terdiri dari pria dan wanita. Karakter androgini dapat dilihat dari tempat kerja tersebut, dimana seorang laki-pria dapat mengerjakan pekerjaan seorang perempuan dan beberapa mereka juga memiliki karakter feminin sekaligus maskulin, sedangkan pada wanita kedua karakter tersebut juga dapat dimilikinya dan mereka juga mampu merealisasikannya dalam kehidupan sehari-hari.

\section{METODE PENELITIAN}

Pengambilan sampel sebanyak 39 subyek dan sejumlah sampel diperoleh dari dua tempat kerja dimana masingmasing subyek 22 subyek terdiri dari 16 subyek perempuan dan 6 subyek laki-laki yang berada di Cafe Rumah Pohon dan 17 subyek terdiri dari 2 subyek perempuan dan 15 subyek laki-laki di Anonimo Coffee.

Teknik pengambilan sampel yang digunakan dalam penelitian adalah purposive sampling, yaitu dengan memilih kelompok subjek yang didasarkan pada 
ciri-ciri atau sifat-sifat populasi yang sudah diketahui sebelumnya yang sesuai dengan maksud dan tujuan penelitian.

Dalam penelitian ini sampel yang diteliti sesuai dengan karakteristik sampel sebagai berikut:

1. Laki-laki dan Perempuan

2. Berdomisili di Medan

3. Memiliki karakteristik perilaku androgini

4. Bekerja di Cafe Rumah Pohon dan Anonimo Coffee

Penelitian ini menggunakan metode skala. Metode skala yang digunakan hanya satu skala yakni untuk mengukur perilaku androgini di tempat kerja dan untuk mengungkap berapa besar perbedaan perilaku androgini pada masing-masing subyek di tinjau dari tempat kerja. Skala ini disusun berdasarkan Metode Guttman dimana tipe pilihan atau tipe item diberi dua pilihan jawaban yang telah disediakan yakni ya dan tidak. Skala ini berisi 52 item. Subyek diminta untuk memilih satu pilihan jawaban "ya atau tidak" yang sesuai menurut pribadi subyek.

Metode analisis data yang digunakan untuk persiapan hipotesis dalam penelitian ini adalah teknik analisis Parametric Analyze of Variance (ANOVA). Hal ini dilakukan mengingat penelitian ini akan melihat perbedaan perilaku androgini antara karyawan Cafe Rumah Pohon dan Anonimo Coffee. Uji hipotesis ANOVA dengan menggunakan perangkat lunak SPSS.

\section{HASIL DAN PEMBAHASAN}

Berdasarkan hasil perhitungan Analisis 1 Jalur, dapat diketahui bahwa terdapat perbedaan perilaku androgini antara karyawan Cafe Rumah Pohon (CRP) dengan karyawan Anonimo Coffee (AC) $\quad(\mathrm{F}=16,874$ dengan $\mathrm{p}=0,000<$ 0,050). Yaitu perilaku androgini pada karyawan Cafe Rumah Pohon lebih tinggi Anonimo Coffee dari karyawan. Dengan demikian, hipotesis dalam penelitian ini dinyatakan diterima.

Hal ini sejalan dengan pendapat yang dikemukakan oleh Heilbrun yang menyatakan bahwa androgini merupakan peran jenis yang memiliki skor yang tinggi baik sifat feminin maupun maskulin dan peran jenis androgini ini bisa terdapat pada jenis kelamin perempuan atau lakilaki. Sejalan dengan pendapat Heilburn, menurut Bem, individu yang feminin adalah seseorang memiliki angka yang tinggi pada sifat feminin dan memiliki angka rendah dari sifat maskulin, individu yang maskulin adalah seseorang yang memiliki angka yang tinggi pada sifat maskulin dan memiliki angka yang rendah pada sifat feminin. Individu androgini adalah laki-laki atau perempuan yang 
memiliki angka tinggi pada sifat maskulin dan feminin.

Dalam hal ini, perilaku androgini ini dapat ditemukan pada individu yang berjenis kelamin laki-laki ataupun perempuan. Berdasarkan pendapat tradisional menyatakan bahwa orang yang sehat itu adalah orang yang memiliki peran jenis sesuai dengan jenis kelaminnya namun pendapat seperti itu saat ini haruslah dikoreksi. Saat ini orang mulai berpendapat bahwa orang yang sehat adalah orang yang mempunyai sifat androgini (dalam Supriyanto, 2005).

Dalam pandangan tradisional, fungsi utama wanita dalam keluarga adalah membesarkan dan mendidik anak (Suprapto, 1985 dalam Arianta, I. L \& Azwar, S, 1993). Shaevitz (1991, dalam Arianta, I. L \& Azwar, S, 1993) mengatakan bahwa sosialisasi yang tradisional mengarahkan seorang gadis untuk menjadi ibu, istri, dan pengelola rumah. Hal ini mendukung sosialisasi peran yang berorientasi feminin. Di sisi lain, menjadi pencari nafkah atau bekerja di luar rumah yang harus didukung dengan karakteristik seperti kemauan kuat, mandiri, dan kompetitif, merupakan ciri-ciri maskulin (Bem, 1981 dalam Arianta, I. L \& Azwar, S, 1993).

Dengan melihat banyaknya partisipasi pekerja wanita pada Cafe
Rumah Pohon dengan jumlah 16 wanita dan 6 pria maka dapat disimpulkan bahwa peran sebagai pencari nafkah dan beberapa ciri maskulinitas ada pada wanita bukan hanya pada pria saja.

Hal ini juga menjadi topik atau inti dari penelitian bahwa karyawan Cafe Rumah Pohon yang didominasi oleh wanita lebih tinggi dibanding dengan karyawan Anonimo Coffee yang didominasi oleh kaum pria. Namun bukan berarti pada karyawan Anonimo Coffee tidak memiliki karakteristik tersebut, hanya saja kategori berperilaku androgininya adalah cukup atau sedang yang artinya bahwa pada beberapa karyawan Anonimo Coffee memiliki karakteristik androgini sedangkan beberapanya tidak memilki karakteristik perilaku androgini.

\section{PENUTUP}

\section{Simpulan}

Berdasarkan hasil yang telah diperoleh dalam penelitian ini, maka dapat disimpulkan beberapa hal sebagai berikut.

Terdapat perbedaan yang signifikan pada perilaku androgini antara karyawan Cafe Rumah Pohon (CRP) dengan karyawan Anonimo Coffee (AC) (F beda $=16,874, \mathrm{p}=0.000<0.050)$.

Karyawan Cafe Rumah Pohon (CRP) memiliki perilaku androgini lebih tinggi daripada karyawan Anonimo Coffee 
(AC), sedangkan perilaku androgini Anonimo Coffee (AC) berada pada kategori cukup memadai.

\section{DAFTAR PUSTAKA}

Arif, I.S. (2006). Dinamika Kepribadian. Bandung : PT. Refika Aditama.

Arikunto, Suharsimi. (1997). Prosedur Penelitian, Rineka Cipta. Jakarta.

Arinta, I.L., \& Azwar, S. (1993). Peran Jenis Androgini dan Konflik Peran-Ganda pada Ibu Bekerja. Jurnal Psikologi. Yogyakarta : Universitas Gajah Mada.

Artikel Fashion. (2013). Androgini. diakses pada tanggal 30 Oktober 2015 pukul 12.45 dari http://kvltmagz.co/androgini-lakilaki-atau-perempuan/.

Azwar, 2012. Reliabilitas dan Validitas. Yogyakarta: Pustaka Pelajar.

Chaplin, J.P. (2011). Kamus Lengkap Psikologi (rev. ed.). Jakarta : PT. Raja Grafindo Persada.

Eka. D.H.N. (2016). Konsep Perilaku Manusia. Diakses pada tanggal 14 januari 2016 pukul 12:18 dari http://dianhusadanuruleka.blogspot .com/p/konsep-perilakumanusia.html

Elqorni, A.K. (2014). Konsep Perilaku Individu dalam Organisasi. Diakses pada tanggal 27 Oktober 2015 pukul 09:37 www.wordpress.com.

Google. Tempat Kerja. Diakses pada tanggal 09 September 2016 dari https://www.scribd.com
Hartanti, L. (2012). Persepsi Karir dalam Gender. Diakses pada tanggal 27 Oktober 2015 pukul 09:54 dari http://lanny.mhs.narotama.ac.id/20 12/07/21/presepsi-karir-dalamgender/.

Istiana. Diktat Psikologi Lintas Budaya. (rev. ed). Medan: Universitas Medan Area.

Kisworo, R.D. (2008). Persepsi Identitas Gender Dan Konsep Diri Tentang Peranan Gender Dikalangan Mahasiswa. Skripsi. Bogor : Institut Pertanian Bogor.

Matondang, Z. (2009). Validitas Dan Reliabilitas Suatu Instrumen Penelitian. Jurnal PPS Vol. 6 No. 1. Medan: Tabularasa PPS UNIMED.

Nazir, M. (1999). Metode Penelitian. Jakarta : Ghalia Indonesia.

Putri, S. A. P. 2012. Karir Dan Pekerjaan Di Masa Dewasa Awal Dan Dewasa Madya. Jurnal Psikologi Vol. III No. 3, 193-212. Semarang: Majalah Ilmiah Informatika.

Santrock, J.W. (ed.) (1997-2011). Perkembangan Masa Hidup Jilid II (Terjemahan). (13 ${ }^{\text {th }}$.ed.). Jakarta : Penerbit Erlangga.

Santrock, J.W. (ed.) (1983-1995). Perkembangan Masa Hidup Jilid I (Terjemahan). (5 $5^{\text {th }}$. ed. $)$. Jakarta : Penerbit Erlangga.

Sears, D.O., Freedman, J.L, \& Peplau, L.A. (1985) Psikologi Sosial Jilid II $\left(5^{\text {th }}\right.$. ed.). Jakarta : Penerbit Erlangga. 
Sugiyono. (2008). Metode Penelitian Kuantitatif Kualitatif dan R\&D. Bandung : Alfabeta.

Supriyanto, A. (2005). Pemasalan Olahraga Melalui Sifat Androgini Pada Anak Sejak Dini. Seminar Nasional Pengembangan Ipteks Olahraga. Surabaya: Hotel Hilton.

Tim Pustaka Agung Harapan. (2012). Kamus Ilmiah Populer. Pustaka Agung Harapan

Tim Dosen. (2015). Pedoman Penyusunan Skripsi. Medan : Universitas Medan Area Fakultas Psikologi.
Upton, P. (2012). Psikologi Perkembangan. Jakarta : Penerbit Erlangga.

Wade, C. (ed.) (2007). Psikologi Jilid I ( $9^{\text {th }}$. ed. $) . \quad$ Jakarta : Penerbit Erlangga.

Wade, C. (ed.) (2007). Psikologi Jilid II $\left(9^{\text {th }}\right.$.ed.). Jakarta : Penerbit Erlangga.

Yusuf, L. N. S. (2001). Psikologi Perkembangan Anak dan Remaja. Bandung: Remaja Rosdakarya. 